\title{
Serum non-organ specific autoantibodies in human immunodeficiency virus 1 infection
}

\author{
F Cassani, L Baffoni, E Raise, L Selleri, M Monti, L Bonazzi, F M Gritti, F B Bianchi
}

\begin{abstract}
Serum samples from 66 seropositive subjects ( 56 with a history of intravenous drug abuse), including asymptomatic carriers and patients with persistent generalised lymphadenopathy (PGL), AIDS related complex (ARC), and AIDS, were tested by indirect immunofluorescence on rat tissue sections and HEp-2 cells for the presence of antibodies to nuclei, smooth muscle, intermediate filaments (anti-IMF) and microfilaments (anti-MF). Counterimmunoelectrophoresis was also used to detect antibodies to extractable nuclear antigens. Smooth muscle antibodies with the $V$ pattern or antinuclear antibodies, mainly of the speckled type, or anti-IMF, occurred in 35 cases, being widely distributed in all groups. Such an autoantibody response resembles the "viral" autoimmunity described in various infectious diseases and in particular that of non-A, non-B post-transfusion hepatitis.
\end{abstract}

Autoantibodies may be of some prognostic relevance, as the prevalence of smooth muscle antibodies $V$ increased as the disease progressed (asymptomatic carriers $20 \%$, those with PGL $29 \%$, those with ARC $47 \%$, and those with AIDS $63 \%$. In the PGL group autoantibody positivity correlated with the presence of skin anergy. The fact that autoantibodies were more frequently detected in patients with circulating immune complexes suggests that these can contain autoantibodies and the corresponding autoantigens.

Semeiotica Medica, Istituto di Clinica Medica Generale e Terapia Medica, Università di Bologna F Cassani

L Baffoni

L Selleri

F B Bianchi

Divisione Malattie Infettive, Ospedale CA Pizzardi, Bologna

E Raise

M Monti

F M Gritti

L Bonazzi

Correspondence to: Professor FB Bianchi, Cattedra di Semeiotica Medica, Istituto di Clinica Medica Generale e Terapia Medica, Policlinico S Orsola Via Massarenti 9, 40138 Bologna, Italy.

Accepted for publication 26 July 1990

Contrasting immune features coexist in human immunodeficiency virus (HIV) type 1 infection. On the one hand, a progressive decrease in numbers of CD4 lymphocytes and an attendant loss of function occurs: this leads to a variety of opportunistic infections and, possibly, tumours. ${ }^{12}$ On the other hand, hypergammaglobulinemia due to B cell polyclonal activation ${ }^{3}$ and serological, ${ }^{4-10}$ as well as clinical, ${ }^{112}$ manifestations of autoimmunity develop. Little is known about non-organ specific serum autoantibodies in HIV infection: antinuclear antibodies have been reported as absent, ${ }^{13}$ but data on other autoantibodies such as those directed to smooth muscle and cytoskeleton components are scarce.
To test whether HIV associated hypergammaglobulinemia can be at least in part due to the development of autoimmune phenomena, we studied patients with the full clinical spectrum of HIV pathology for the presence of a panel of non-organ specific autoantibodies. We also wanted to determine the relevance of CD4 lymphocyte function in the genesis of autoantibodies.

\section{Methods}

Sixty six subjects positive for serum antibodies to HIV 1 by enzyme linked immunosorbent assay (ELISA) or Western blot assay, or both, were studied. The male: female ratio was $2.9(49: 17)$ and the median age was 24 years (range $3-48$ ). They included $56(85 \%)$ intravenous drug abusers, nine $(14 \%)$ homosexual men, and one child infected in utero. They were categorised as follows: 15 asymptomatic carriers (group II, according to the Centers for Disease Control classification system), ${ }^{14} 28$ patients with persistent generalised lymphadenopathy (PGL) and no constitutional symptoms (group III), 15 with AIDS related complex (ARC) (group IV-A), and eight with overt AIDS (group IV-B, C, and D). The control group included 20 intravenous drug abusers (male:female ratio 3, median age 25 years) negative for HIV antibodies by both ELISA and Western blot assay. In all seropositive subjects the following variables were evaluated: number of circulating CD4 lymphocytes and CD4:CD8 ratio, platelet count, serum concentration of total immunoglobulins and their IgG, IgA, and $\operatorname{IgM}$ fractions, presence of circulating immune complexes (detected by a Clq binding enzyme immunoassay) and skin anergy (no response to any of the following antigens: tetanus, diphtheria, tuberculin, Candida,
Sera were stored at $-20^{\circ} \mathrm{C}$ until use.

Indirect immunofluorescence was performed according to standard procedures ${ }^{15}$ on cryostat sections of rat tissues (kidney and liver) and cultured HEp-2 cells (Kallestad, Austin, Texas, USA). The former was used to detect smooth muscle antibodies and antinuclear antibodies, the latter antinuclear antibodies, antibodies to intermediate filaments (anti-IMF), and microfilaments (anti-MF). Sera were screened at a 1 in 40 dilution. Smooth muscle antibodies and antinuclear antibodies patterns were defined on kidney sections and HEp-2 cells, respectively, according to accepted criteria. ${ }^{1617}$ 


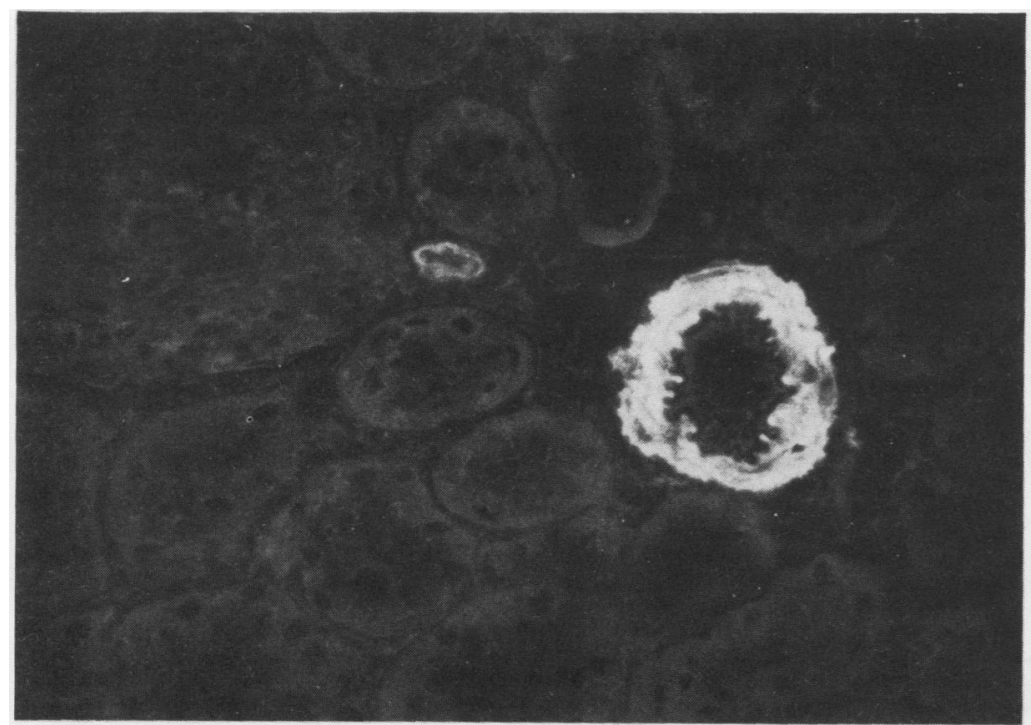

Figure 1 Immunofluorescence on rat kidney section. Serum from a patient with AIDS: Smooth muscle antibodies with the V pattern: isolated positivity of smooth muscle cells of vessel walls.

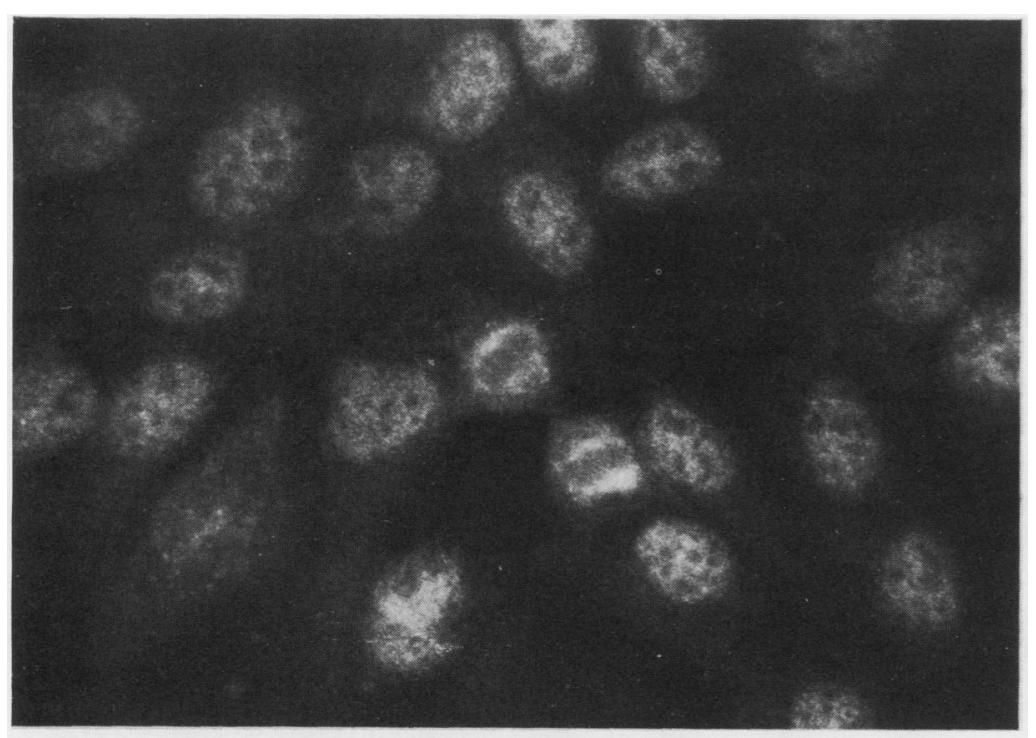

Figure 2 Immunofluorescence of HEp-2 cells. Serum from a patient with ARC. Antinuclear antibodies with speckled pattern.

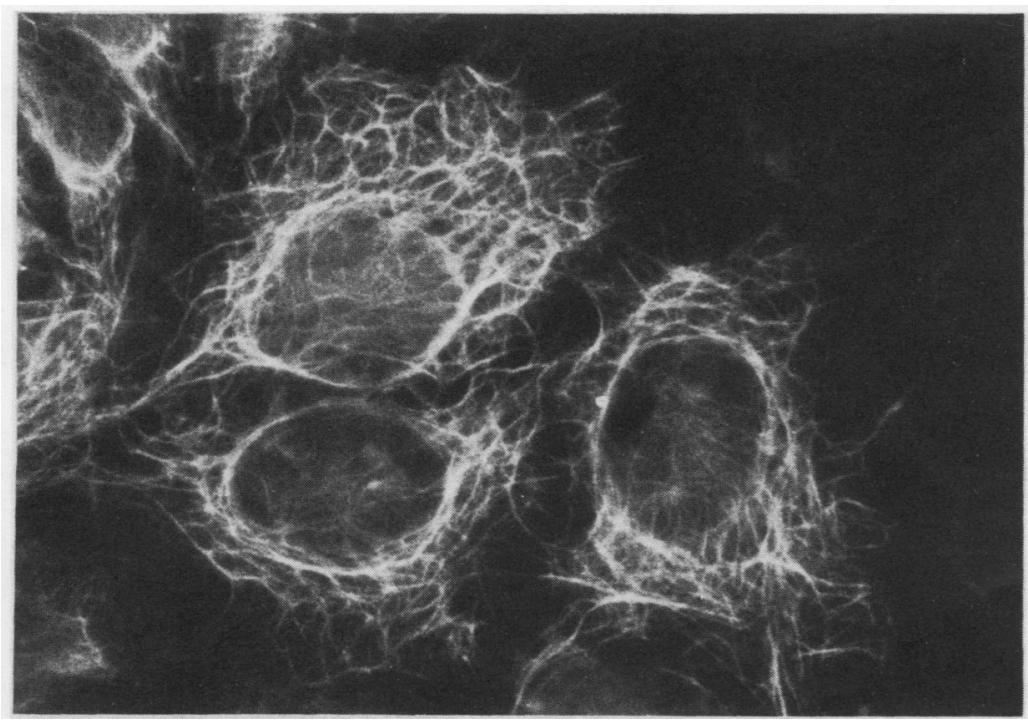

Figure 3 Immunofluorescence on HEp-2 cells. Serum from a patient with AIDS. Anti-IMF.
Positive reactions detected in the subjects with HIV antibodies were titrated by serial dilutions to the end point using a fluorescein isothyocyanate, conjugated sheep anti-human $\mathrm{F}(\mathrm{ab})_{2}$ (Wellcome Diagnostics, Dartford, England), and the immunoglobulin class of the autoantibodies was assessed by the use of monospecific fluorescein isothyocyanate conjugated rabbit anti-human IgG, IgA, and IgM (Boeringwerke, Marburg, West Germany).

Antibodies to extractable antigens, nuclear (anti-ENA), and non-nuclear, were searched for as previously described. ${ }^{18} \mathrm{~A}$ saline extract of lyophilised rabbit thymus acetone powder (Pel-Freez Biologicals, Rogers, Arkansas, USA) was used as source of the antigens.

The following tests were applied according to their own indications: the $\chi^{2}$ test with or without Yates' correction, the trend $\chi^{2}$ test, Fisher's exact test and the Wilcoxon twotailed test.

\section{Results}

As expected, patients with AIDS had a median number of $\mathrm{CD} 4$ lymphocytes $(170 \times$ $\left.10^{6} / 1\right)$ and a median CD4:CD8 ratio $(0 \cdot 16)$ lower than that of asymptomatic carriers ( 569 and $1 \cdot 19$, respectively), PGL $(747,1.02)$, and ARC patients $(643,0.79)(\mathrm{p}<0.05$ to $<0.001$, Wilcoxon). Similarly, patients with AIDS exhibited skin anergy at a higher prevalence $(100 \%)$ than each of the remaining groups (asymptomatic carriers 0\%, PGL $25 \%$, ARC $40 \%)(\mathrm{p}<0.02$ to $<0.0001$, Fisher's exact test). In particular, the occurrence of skin anergy increased as the disease progressed $\left(p<0.004, \chi^{2}\right)$. No significant difference was recorded among asymptomatic carriers and patients with PGL, ARC, and AIDS with respect to sex, age, and any of the other laboratory variables considered.

The autoantibody state is reported in table 1. Smooth muscle antibodies with the $\mathrm{V}$ pattern (isolated positivity of smooth muscle cells of vessel walls), antinuclear antibodies mainly of the speckled type, and anti-IMF occurred with similar overall prevalences in the seropositive population $(35 \%, 27 \%$, and $29 \%$, respectively) as well as in seronegative controls $(25 \%, 15 \%$, and $25 \%$, respectively). Smooth muscle antibodies with the G or T pattern-positivity of vessel walls plus glomerular $(G)$ or peritubular structures $(T)$, homogeneous antinuclear antibodies, antiMF, and antibodies to extractable antigens were consistently absent. In particular, the smooth muscle antibodies $\mathrm{V}$ prevalence showed a significant trend to increase with the progression of the disease (asymptomatic carriers $20 \%$, PGL $29 \%$, ARC $47 \%$, AIDS $63 \%: p<0.05)$. Smooth muscle antibodies and anti-IMF occurred independently from each other in both seropositive and control cases. Thirty five of the $66(53 \%)$ seropositive subjects were positive for at least one autoantibody, and 19 of them exhibited the coexistence of two or more distinct specificities. Autoantibodies occurred with similar 
Table 1 Serum smooth muscle antibodies, antinuclear antibodies, and antibodies against intermediate filaments, microfilaments, and extractable antigens in HIV positive study population and controls (HIV negative intravenous drug abuse)

\begin{tabular}{|c|c|c|c|c|c|c|}
\hline & $\begin{array}{l}\text { Asymptomatic } \\
\text { carriers } \\
(n=15)\end{array}$ & $\begin{array}{l}\text { Patients with PGL } \\
(n=28)\end{array}$ & $\begin{array}{l}\text { Patients with } A R C \\
(n=15)\end{array}$ & $\begin{array}{l}\text { Patients with AIDS } \\
(n=8)\end{array}$ & $\begin{array}{l}\text { Total HIV } \\
(n=66)\end{array}$ & $\begin{array}{l}\text { Controls } \\
(n=20)\end{array}$ \\
\hline \multicolumn{7}{|l|}{ Immunofluorescence on tissue sections: } \\
\hline $\begin{array}{l}\text { Smooth muscle antibodies } \\
\text { V pattern } \\
\text { G-T pattern } \\
\text { antinuclear antibodies }\end{array}$ & $\begin{array}{l}3(20 \%) \\
0 \\
0\end{array}$ & $\begin{array}{l}8(29 \%) \\
0 \\
0\end{array}$ & $\begin{array}{l}7(47 \%) \\
0 \\
1(7 \%)\end{array}$ & $\begin{array}{l}5(63 \%)^{\star} \\
0 \\
0\end{array}$ & $\begin{array}{c}23(35 \%) \\
0 \\
1(2 \%)\end{array}$ & $\begin{array}{l}5(25 \%) \\
0 \\
2(10 \%)\end{array}$ \\
\hline \multicolumn{7}{|l|}{ Immunofluorescence on HEp-2 cells } \\
\hline $\begin{array}{l}\text { Antinuclear antibodies } \\
\text { speckled } \\
\text { nucleolar } \\
\text { homogeneous } \\
\text { all patterns } \\
\text { Anti-IMF } \\
\text { Anti-MF }\end{array}$ & $\begin{array}{l}4(27 \%) \\
1(6 \%) \\
0 \\
5(33 \%) \\
3(20 \%) \\
0\end{array}$ & $\begin{array}{l}7(25 \%) \\
1(4 \%) \\
0 \\
8(29 \%) \\
7(25 \%) \\
0\end{array}$ & $\begin{array}{l}3(20 \%) \\
1(7 \%) \\
0 \\
4(27 \%) \\
6(40 \%) \\
0\end{array}$ & $\begin{array}{l}1(12 \%) \\
0 \\
0 \\
1(12 \%) \\
3(37 \%) \\
0\end{array}$ & $\begin{array}{l}15(23 \%) \\
3(4 \%) \\
0 \\
18(27 \%) \\
19(29 \%) \\
0\end{array}$ & $\begin{array}{l}3(15 \%) \\
0 \\
0 \\
3(15 \%) \\
5(25 \%) \\
0\end{array}$ \\
\hline \multicolumn{7}{|l|}{ CIE } \\
\hline Antibodies to extractable antigens & 0 & 0 & 0 & 0 & 0 & 0 \\
\hline
\end{tabular}

$\star:$ AsC $\rightarrow$ PGL $\rightarrow$ ARC $\rightarrow$ AIDS $\mathrm{p}<0.05$ ( $\chi^{2}$ test $)$.

Immunofluorescence: 1 in 40 serum dilution. Counterimmunoelectrophoresis: undiluted serum).

Table 2 Titre and class of serum smooth muscle antibodies, antinuclear antibodies, and antibodies to intermediate filaments (detected in HIV positive subjects by indirect immunofluorescence on rat kidney sections and HEp-2 cells

\begin{tabular}{|c|c|c|c|c|c|c|c|c|c|c|c|c|}
\hline & \multicolumn{5}{|c|}{ Titre } & \multicolumn{7}{|c|}{ Ig class } \\
\hline & $n=$ & $1 / 40$ & $1 / 80$ & $1 / 160$ & $\geqslant 1 / 320$ & $G$ & $A$ & $M$ & $G+A$ & $G+M$ & $A+M$ & $G+A+M$ \\
\hline $\begin{array}{l}\text { Smooth muscle antibodies } \\
\text { Antinuclear antibodies } \\
\text { anti-IMF }\end{array}$ & $\begin{array}{l}23 \\
18 \\
19\end{array}$ & $\begin{array}{r}15 \\
11 \\
8\end{array}$ & $\begin{array}{l}5 \\
2 \\
6\end{array}$ & $\begin{array}{l}1 \\
4 \\
4\end{array}$ & $\begin{array}{l}2 \\
1 \\
1\end{array}$ & $\begin{array}{r}9 \\
11 \\
4\end{array}$ & - & $\begin{array}{l}- \\
2 \\
7\end{array}$ & $\frac{7}{-}$ & $\begin{array}{l}1 \\
2 \\
6\end{array}$ & $\overline{1}$ & $\begin{array}{l}4 \\
2 \\
1\end{array}$ \\
\hline
\end{tabular}

prevalences in seropositive subjects with and without a history of intravenous drug abuse (31/56, 55\%, and $4 / 10,40 \%$, respectively). The number of patients with autoantibodies was $53 \%$ (eight of 15 ) in the asymptomatic carriers, $46 \%$ (13 of 28 ) in those with PGL, $53 \%$ (eight of 15) in those with ARC, $75 \%$ (six of eight) in those with AIDS and $55 \%(11$ of 20) in the control group. The number of antinuclear antibodies positive cases considerably increased when HEp-2 cells instead of tissue sections were used (21 compared with three).

Titre and class of autoantibodies detected in seropositive subjects are reported in table 2 . Most positive reactions, (47 of $60,78 \%$ ) were at a low titre $(1 / 40$ or $1 / 80)$. No significant variation of the titre was observed among the various clinical groups. The commonest immunoglobulin class was IgG for both smooth muscle antibodies ( 21 of $23,91 \%$ ) and antinuclear antibodies ( 15 of $18,83 \%$ ), but
IgM for anti-IMF (14 of 19, 74\%). In 25 of the $60(42 \%)$ positive reactions the autoantibody belonged to at least two distinct classes.

Table 3 shows the comparison of sex, age, and laboratory variables between seropositive patients with and without autoantibodies. Circulating immune complexes were more frequently detected in the autoantibody positive (20 of $35,57 \%$ ) than negative cases (eight of $31,26 \%)\left(p<0.02, \chi^{2}\right.$ test). In the PGL group, besides the association with serum immune complexes ( $p<0.01$ ), the occurrence of autoantibodies correlated with the presence of skin anergy $(p<0.005)$.

\section{Discussion}

This study provides evidence that serum nonorgan specific autoantibodies occur in about $50 \%$ of HIV 1 positive patients, most of them with a history of intravenous drug abuse, and

Table 3 Comparison between presence of serum autoantibodies (smooth muscle or antinuclear, or intermediate filaments antibodies) and sex, age, and laboratory variables in HIV positive subjects

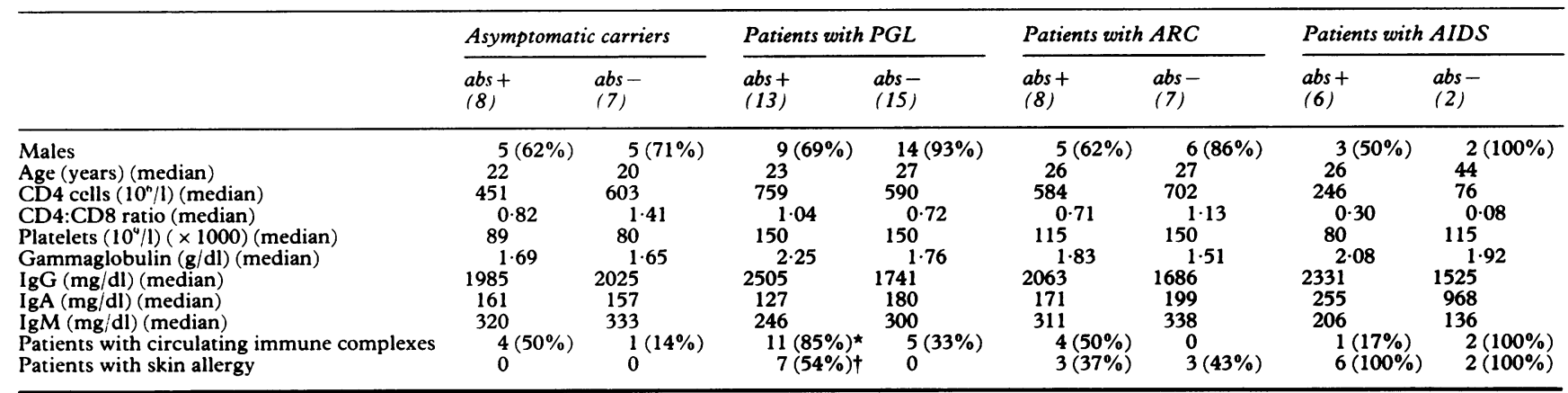

*abs + vs abs $-\mathrm{p}<0.01$ (Fisher's exact test)

tabs + vs abs $-\mathrm{p}<0.005$ (Fisher's exact test). 
that they are widely distributed across the clinical spectrum of HIV infection, from asymptomatic carriers to patients with overt AIDS. In a previous study smooth muscle antibodies and antinuclear antibodies were not detected by immunofluorescence on mouse liver sections in a large series of homosexua men with ARC and AIDS. ${ }^{13}$ Such a discrepancy may be due to technical reasons, because mouse liver is not the substrate of choice for the detection of smooth muscle antibodies ${ }^{16}$ and is less sensitive than HEp-2 cells for the demonstration of antinuclear antibodies. ${ }^{192}$ Selection of seropositive subjects belonging to different risk groups could also be relevant. In our small series no significant difference in autoantibody prevalence occurred between intravenous drug abusers and homosexual men. Further studies on larger series, however, are needed to elucidate this point.

The spectrum of autoimmune reactivities occurring in HIV infection is wide and includes smooth muscle antibodies with the $\mathrm{V}$ pattern, speckled antinuclear antibodies, and antiIMF. The finding of a similar autoimmune state in seronegative drug abusers suggests that these autoantibodies, although compatible with HIV infection, are not specific for it. Drug abuse could itself account for their appearance, presumably because this facilitates the development of infectious diseases. In fact, the above antibody pattern resembles that described in several viral infections characterised by smooth muscle antibodies $\mathrm{V}^{21}$ and IgM antiIMF detected on human fibroblasts. ${ }^{22-26}$ This "viral" autoimmunity seems to be mainly related to vimentin antibodies, which could account for both smooth muscle antibodies $\mathrm{V}^{21}$ and anti-IMF. ${ }^{27}$ The fact that in our series the two antibodies did not occur together and belonged to different immunoglobulin classes would favour an effect of anti-IMF other than anti-vimentin. It must be borne in mind that the use of epithelial cell lines (HEp-2 cells) as immunofluorescence substrate does not differentiate between anti-IMF with antivimentin and anti-cytokeratin specificity. In fact, both cytoskeletal components are well expressed in epithelial cultures, ${ }^{28}$ as proved by the use of specific monoclonal antibodies. The hypothesis has even been made that both structures share common epitopes. ${ }^{29}$ Indirect evidence has already been produced on the occurrence of anti-cytokeratin anti-IMF in a viral disease such as hepatitis $\mathrm{C}$ virus (HCV) related post-transfusion hepatitis. ${ }^{30} \mathrm{It}$ is worth mentioning that both $\mathrm{HIV}$ and $\mathrm{HCV}$ virus infections are common in the same risk groups (drug addicts, homosexual men). The recent availability of a test for the detection of $\mathrm{HCV}$ antibodies ${ }^{31}$ should clarify this point.

"Viral" autoimmunity in seropositive subjects is clearly different from that found in connective tissue disease (absence of high titre antinuclear antibodies and anti-ENA -19) and autoimmune chronic liver disease (lack of homogeneous antinuclear antibodies $-20-$ and anti-actin antibodies, identified as smooth muscle antibodies with the $T$ or $G$ pattern
-16-, anti MF -25-, and antibodies against the XR extractable antigen -18 ).

The presence of autoantibodies even in patients with overt AIDS, where a profound impairment of $\mathrm{T}$ cell function occurs, suggests that their expression might be independent of $T$ cells. In particular, autoantibodies might result from polyclonal B lymphocyte activation, a well known immune abnormality induced in seropositive subjects by $\mathrm{HIV}^{32}$ or Epstein-Barr virus superinfection. ${ }^{33}$

In view of our findings, it is worth remembering that Epstein-Barr virus activated human B cells have been shown to secrete antiIMF $^{34}$ with anti-cytokeratin specificity. ${ }^{35}$ The fact that serum immunoglobulin concentrations were similarly raised in patients with and without autoantibodies suggests that their contribution to hypergammaglobulinemia is negligible and that $\mathbf{B}$ cell activation may well occur in HIV infection without autoantibody production. Other mechanisms may, theoretically, be involved, such as a molecular mimicry between viral and cellular constituents. ${ }^{36}$

Serum autoantibodies may be of some prognostic relevance, on clinical grounds. In fact, the presence of smooth muscle antibodies points to an advanced rather than an early stage of the HIV induced disease and, in patients with PGL, autoantibody positivity is significantly associated with a profound impairment of the delayed type hypersensitivity reactions. Finally, serum autoantibodies occur more frequently when circulating immune complexes are found. Whether serum immune complexes in seropositive subjects contain not only HIV antibodies, as already reported, ${ }^{37}$ but also the aforementioned autoantibodies and the corresponding autoantigens, remains to be clarified.

This study was supported by CNR, grant No 87.01532.04

1 Lane HC, Fauci AS. Immunologic abnormalities in the acquired immunodeficiency syndrome. Ann Rev Immunol acquired immun

2 Seligmann M, Pinching AJ, Rosen FS, et al. Immunology of human immunodeficiency virus infection and the acquired immunodeficiency syndrome. An update. Ann Intern Med 1987;107:234-42.

3 Lane HC, Masur H, Edgar LC, Whalen G, Rook AH, Fauci AS. Abnormalities of B-cell activation and immunoregulation in patients with the acquired immunodeficiency syndrome. $N$ Engl J Med 1983;309:453-8.

4 Bettaieb A, Oksenhendler E, Fromont P, Duedari N, Bierling P. Immunochemical analysis of platelet autoantibodies in HIV-related thrombocytopenic purpura: a antibodies in HIV-related thrombocytopenic purpura

5 Silvestris F, Edwards BS, Sadeghi OM, Frassanito MA Williams RC Jr, Dammacco F. Isotype, distribution and target analysis of lymphocyte reactive antibodies in patients with human immunodeficiency virus infection. Clin Immunol Immunopathol 1989;53:329-40.

6 Stricker RB, McHugh TM, Moody D, et al. An AIDSrelated cytotoxic autoantibody reacts with a specific antigen on stimulated CD4 + T cells. Nature 1987; 327:710-13.

7 Golding H, Shearer GM, Hillman $\mathrm{K}$, et al. Common epytope in human immunodeficiency virus (HIV) I-GP4 and HLA class II elicits immunosuppressive autoantibodies capable of contributing to immune dysfunction in HIV I-infected individuals. JClin Invest 1989;83:1430-5.

8 Cohen $H$-infected individuals. J Clin Invest 1989;83:1430-5. Machin SJ. Lupus anticoagulant, anticardiolipin Machin SJ. Lupus anticoagulant, anticardiolipin antibodies and human immunodeficienc

9 Kowalsky M, Ardman B, Basiripour L, et al. Antibodies to CD4 in individuals infected with human immunodeficiency virus type 1. Proc Natl Acad Sci USA 1989;86:3346-50. 
10 Bost KL, Hahn BH, Saag MS, Shaw GM, Weigent DA, Blalock JE. Individuals infected with HIV possess antibodies against IL-2. Immunology 1988;65:611-5.

11 Wichester R, Bernstein DH, Fischer HD, Enlow $R$ Solomon $\mathrm{G}$. The co-occurrence of Reiter's syndrome and acquired immunodeficiency. Ann Intern Med 1987; acquired $106: 19-26$.

12 Calabrese LH. Autoimmune manifestations of human immunodeficiency virus (HIV) infection. Clin Lab Med 1988;8:269-79.

13 Solinger AM, Adams LE, Friedman-Kien AE, Hess EV. Acquired immune deficiency syndrome (AIDS) and autoimmunity-Mutually exclusive entities? J Clin Immunol 1988;8:32-42.

14 Centers for Disease Control. Classification system for human T-lymphotropic virus type III/lymphadenopathy-associated virus infections. Ann Intern Med 1986;105:234-7.

15 Roitt IM, Doniach D. Manual of autoimmune serology. Geneva: World Health Organization, 1969.

16 Bottazzo GF, Florin-Christensen A, Fairfax A, Swana G Doniach D Gröeschel-Stewart U. Classification of smooth muscle autoantibodies (SMA) detected by immunofluorescence. J Clin Pathol 1976;29:403-10.

17 Bernstein RM, Steigerwald JC, Tan EM. Association of antinuclear and antinucleolar antibodies in progressive systemic sclerosis. Clin Exp Immunol 1982;48:43-51.

18 Cassani F, Fusconi M, Bianchi FB, et al. Precipitating antibodies to rabbit thymus extractable antigens in chronic liver disease: relationship with anti-actin antibodies. Clin Exp Immunol 1987;68:588-95.

19 Tan EM. Autoantibodies to nuclear antigens: their immunobiology and medicine. Adv Immunol 1982;33:167-240.

20 Cassani F, Bianchi FB, Lenzi M, Volta U, Pisi E Immunomorphological characterisation of antinuclear Immunomorphological characterisation of antinuclear antibodies in

21 Toh BH. Smooth muscle autoantibodies and autoantigens. Clin Exp Immunol 1979;38:621-8.

22 Toh BH, Yildiz A, Sotelo J, et al. Viral infections and IgM autoantibodies to cytoplasmic intermediate filaments. Clin Exp Immunol 1979;37:76-82.

23 Pedersen JS, Toh H, Locarnini SA, Gust ID, Shyamala GN Autoantibody to intermediate filaments in viral hepatitis. Clin Immunol Immunopathol 1981;21:154-61.

24 Bretherton L, Toh BH. IgM autoantibody to intermediate filaments in infectious mononucleosis. J Clin Lab Immunol flaments in infe

25 Pedersen JS, Toh BH, Mackay IR, et al. Segregation of autoantibody to cytoskeletal filaments, actin and inter- mediate filaments, with two types of chronic active hepatitis. Clin Exp Immunol 1982;48:527-32.

26 Zauli D, Crespi C, Bianchi FB, Craxi' A, Pisi E Autoimmunity in chronic liver disease caused by hepatitis delta virus. J Clin Pathol 1986;39:897-9.

27 Brown C, Pedersen JS, Underwood JR, Gust ID, Toh BH. Autoantibodies to intermediate filaments in acute viral hepatitis $A, B$ and non- $A$, non-B are directed against vimentin. J Clin Lab Immunol 1986;19:1-4.

28 Senecal JL, Rothfield NF, Oliver JM. Immunoglobulin $M$ autoantibody to vimentin intermediate filaments. J Clin Invest 1982;69:716-21.

29 Pruss RM, Mirsky R, Raff MC, Thorpe R, Dowding AJ, Anderton $\mathrm{BH}$. All classes of intermediate filaments share a common antigenic determinant defined by a monoclonal antibody. Cell 1981;27:419-28.

30 Cassani F, Tremolada F, Baffoni L, et al. Markers of "viral" autoimmunity in chronic non-A, non-B post-transfusion hepatitis. Ital J Gastroenterol 1988;20:171-4.

31 Kuo G, Choo QL, Alter JH, et al. An assay for circulating antibodies to a major etiologic virus of human non-A, nonB hepatitis. Science 1989;244:362-4.

32 Schnittman SM, Lane HC, Higgins SE, Folks T, Fauci AS Direct polyclonal activation of human $B$ lymphocytes by the acquired immunodeficiency syndrome virus. Science 1986;233:1084-6.

33 Yarchoan R, Redfield RR, Broder S. Mechanisms of B cel activation in patients with acquired immunodeficiency syndrome and related disorders. J Clin Invest 1986; 78:439-47.

34 Mortazavi-Milani SM, Stierle HE, Holborow EJ. In vitro induction of anti-intermediate filament antibody in lymphocyte cultures by Epstein-Barr virus. Immunol Let 1982;5:203-5.

35 Viac J, Paire J, Desgranges C, Iwatsuki K, Thivolet J. Epstein-Barr virus-transformed lymphocytes from patients with bullous diseases produce autoantibodies to patients with bullous diseases produce autoantibodies to
cytokeratins. Clin Immunol Immunopathol 1986;39: cytokera

36 Fujinami RS, Oldstone MBA, Wroblewska Z, Frankel ME, Koprowski H. Molecular mimicry in virus infection cross-reaction of measles virus phosphoprotein or of herpes simplex virus protein with human intermediate filaments. Proc Natl Acad Sci USA 1983;80:2346-50.

37 Morrow WJW, Wharton M, Stricker RB, Levy JA. Circulating immune complexes in patients with acquired immune deficiency syndrome contain the AIDS associated retrovirus. Clin Immunol Immunopathol 1986;40:515-24. 